\title{
Isolation of Some Bacterial and Mycotic Infection from Eyes of Dogs in Baghdad
}

\author{
D.O.I - 10.51201/12515 \\ https://doi.org/10.51201/12515
}

\section{Amanee M. Radhy 1, Naseir Mohammed Badawi2* Mohammad Mushgil Zenad 3 and Abdul-Raheem Abdul-Jalil Wali4}

Department of Internal and Preventive Veterinary Medicine, College of Veterinary Medicine, Baghdad University, Iraq 1,2 and 3

Baghdad Veterinary Hospital 4

\begin{abstract}
The aim of the present study was to detect the fungal and bacterialpathogens that infected eyes dogs as pathogenic and non-pathogenic and chance associated with Canine Distemper Virus (CDV). Thirty eyes infected dogs and tenhealthy dogs were came to the Baghdad veterinary hospital, through the period from the March 2016 to the April 2017, the eyes infected dogsappeared signs severe eyes inflammation, lacrimation, eye redness, anorexia, respiratory signs and pus in eyes, followed by clinical examination to the affected dogs, culturing of swabs for estimated the bacterial and fungal pathogens and laboratory diagnosis of suspected dogs on $C D V$, the results exposed significant increase $(P \leq 0.05)$ in the bacterial sporadic causative agent (53.34\%) compare to other types of causative agents, significant increase $(P \leq 0.05)$ in the Staphylococcus spp. (32.14\%) and Escherichia coli (17.8\%) compared with other types of pathogens isolates, the rate of eyes infection was significantly higher $(P \leq 0.05)$ in March and April, the rate of eyes infection was significantly higher $(P \leq 0.05)$ was in Terrier and German shepherd, ); the eyes infection rate wasincreased significantly in males dogs compared to the females dogs and non-effect of age on the infection rate.
\end{abstract}

Key words: Eyes Infection. Fungal, Bacteria, CDV, Dog, Baghdad.

\section{INTRODUCTION}

The normal flora may be became opportunistic pathogens, bacteria and fungi are more commonly isolated (Asghari and Gharachorlou, 2011). The most of bacterial isolations in different animals are gram positive bacteria are Staphylococcus at the first (Gemensky et al., 2005).also, gramnegative andfungal species are isolates as normal ocularflora of the dog,the organisms isolate in ocular depend on the age, sex , geographical area and the climate(Grahn, 2004). Prado (2005) reported in Brasil the commonisolated microorganisms from healthy eyes dogs wereStaphylococcusintermedius. While common pathogens Staphylococcus spp., Streptococcus spp., Bacillus spp., Pseudomonas aeruginosa, Escherichia coli, Neisseria spp., Lactobacillus spp., Pasteurellacanis, Alcaligenesfaecalis, Klebsiellaspp., Francisellaspp. and commonly microorganisms isolated from eyes with disease clinical signs are Staphylococcus spp., Streptococcus spp., Escherichia coli, Bacillus cereus, and Pseudomonas spp. (Miller and Murphy, 1995; Salisbury et al., 1995; Massa et al., 1999; Haghkhah et al., 2005).The types of 
organisms are differences according the geographic area (Gerding and Kakoma, 1990)and the prevalence rates difference according to results dog breed, season, geography and climate (Wang et al., 2008). The eye is typically resistant to primary infection dueto the Many cellular and molecular factors thatprotect eyes against pathogens include corneal nerves, tears, the keratocytes, epithelium, cytokines and polymorpho nuclear cells (Akpek and Gottsch, 2003).

The aim of this study was to isolation and determine of the fungal and bacteria that associated with eye inflammation in dogs are received at Baghdad veterinary hospital through March 2016 to the April 2017.

\section{MATRIAL AND METHODS}

\section{Specimen collection}

Thirtydogs (6 females and 24 males) were examined at a small animal clinic in Baghdad veterinary hospital, during the period from March 2016 to the April 2017. The dogs were suffered from severe eyes inflammation, lacrimation, eye redness and other signs of ocular diseases, these dogs prepared to bacterial and fungal isolation. On the other hand, ten healthy dogs are examined and prepared also to bacterial and fungal isolation as control group. Sterile cotton swab with gently sample should be taken from corneal and conjunctiva area of infected eyes. Two swabs were taken; first without transport medium for fungal cultivation and other swab were used with transport medium for bacterial isolation, then removed cover swaband avoid contact with eyelashes or skin of the eyelids. Placed swab on ice within 24 hours for laboratory culture (Leigueet al., 2016). .

\section{Fungal culturing and identification}

Swabs specific for fungal were deeply cultured on Sabouraud Dextrose Agar (SDA), incubated at $37^{\circ} \mathrm{C}$ for seven days, then morphological characteristics of fungal identification for fungal species diagnosis,and use few drops of lacto phenol cotton blue stain add on the slide with small portion of cultured colonies and covered with the special cover slid and examined under light microscope with low power (10X) and high power (40X) (Ibrahim and Rahma, 2009), the fungal species were diagnosed according to (Cheesbrough, 2000).

\section{Bacterial culturing and identification :}

Sterile swabs with transport media were used in our study, swabs passed direct on inferior conjunctival sac of compromised eye avoiding contact with eyelashes and skin of eyelids. All swabs were inoculated on the following media (5\% Sheep blood agar, MacConkey agar and Nutreint agar) at $37^{\circ} \mathrm{C}$ for 24 to $48 \mathrm{~h}$. If no suspected colonies were observed, plates were kept in incubation for another $48 \mathrm{~h}$ before being considered negative. Isolated microorganisms were identified by colony macroscopic characteristics, Gram staining, and different biochemical tests, according to (Quinn, 2004).

\section{CDV (Canine Distemper Virus) Antigen Detection Kit}

Serum or plasma 2-3 drops into diluent tube and mix it. Sample immediately tested after its dilution. The presence any visible bands on the test band (T) and the control band (C) indicates a positive result (Greene and Apple, 2006) (Soma et al. 2003). 


\section{Statistical Analysis}

Data were analysis by using statistical program (SPSS program version 20), chi-square test used for comparison the results at level significance of $(\mathrm{P} \leq 0.05)$.

\section{RESULTS}

The study was conducted on $40 \mathrm{dogs}$; the dogs of the study divided to two groups the first group 30 dogs suffered from severe eyes inflammation, lacrimation, eye redness, anorexia, respiratory signs and pus in eyes,second group 10 dogs was healthy without any ocular clinical signs, the culture of healthy dogs was negative for fungal and bacteria.

After microbiology culture to the fungal and bacteria the results revealed (Table 1) many causes of eye inflammation was sporadic pathogen and other was mixed pathogens with significant increase $(\mathrm{P} \leq 0.05)$ in the bacterial sporadic causative agent $(53.34 \%)$ compare to other types of causative agents while non-culture samples was (20\%) significant increase $(\mathrm{P} \leq 0.05)$ in the percentage compared to other types of the infection expect bacterial infection types. The mixed eye infection in (Table 1) was 1 case (Klebsiellawith Geotrichum and CDV), 1 case (Escherichia coli and Aspergillus), 1 case (CDV with Salmonella spp.) 1 case (CDV with Aspergillus spp.)

The rate of eyes infection according to types of isolates in Baghdad (Table 2) was significant increase $(\mathrm{P} \leq 0.05)$ in the Staphylococcus spp. (32.14\%) and Escherichia coli $(17.8 \%)$ compared with other types of pathogens isolates.

The rate of eyes infection according to months in Baghdad (Table 3) was increase significantly $(\mathrm{P} \leq 0.05)$ in March and April compared with other months of the years.

The rate of eyes infection according to dogs breeds in Baghdad (Table 4) was significantly higher $(\mathrm{P} \leq 0.05)$ was in Terrier and German shepherd compared with other types of dogs breeds. On the other hand, in the results according the sex (Table 5); the eyes infection rate was significant increase in males dogs (80\%) compared to the females dogs $(20 \%)$. The dogs of study classified according to age three groups (Table 6). The dogs less than 1:year, between 1-4 years and more than five year; and estimated the eyes infection rate, the results showed no significant differences $(\mathrm{P} \leq 0.05)$ between age groups. 
Table ( 1 ). The rate of eyes infection according to mixed, sporadic or non-culture isolates in Baghdad.

\begin{tabular}{|l|c|c|}
\hline Types isolates & Number of isolates & Infection rate from 30 sample \\
\hline $\begin{array}{l}\text { Mixed bacterial, fungal } \\
\text { isolates and CDV }\end{array}$ & $\begin{array}{c}\text { 1(Klebsiellawith } \\
\text { Geotrichum } \text { and CDV) }\end{array}$ & $3.34 \%$ \\
\hline $\begin{array}{l}\text { Mixed bacterial and fungal } \\
\text { isolates }\end{array}$ & $\begin{array}{c}\text { 1(Escherichia coli } \text { and } \\
\text { Aspergillus })\end{array}$ \\
\hline Mixed bacterial and CDV & 1 (wth Salmonella spp.) & $3.34 \%$ \\
\hline $\begin{array}{l}\text { Mixed isolates fungal and } \\
\text { CDV }\end{array}$ & 1 (with Aspergillus spp.) & $3.34 \%$ \\
\hline Fungal isolates only & 4 & $53.34 \%$ \\
\hline Bacterial isolates only & $16^{*}$ & $20 \%$ \\
\hline Non-culture sample & $6^{*}$ & $13.34 \%$ \\
\hline
\end{tabular}

*Refer to presence of significant value vertically at $(\mathrm{P} \leq 0.05)$.

Table ( 2 ). The rate of eyes infection according to types of isolates in Baghdad.

\begin{tabular}{|l|c|c|}
\hline Types isolates & Number of isolates & Infection rate of the isolates \\
\hline Staphylococcus spp. & $9^{*}$ & $32.14 \%$ \\
\hline Streptococcus spp. & 1 & $3.57 \%$ \\
\hline Escherichia coli & $5^{*}$ & $17.8 \%$ \\
\hline Klebsiellaspp. & 2 & $7.14 \%$ \\
\hline Salmonella spp. & 1 & $3.57 \%$ \\
\hline Bacillus spp. & 1 & $3.57 \%$ \\
\hline Geotrichum spp. & 2 & $7.14 \%$ \\
\hline Aspergillus spp. & 3 & $10.71 \%$ \\
\hline Alternaria spp. & 1 & $3.57 \%$ \\
\hline CDV & 3 & $10.71 \%$ \\
\hline
\end{tabular}

*Refer to presence of significant value vertically at $(\mathrm{P} \leq 0.05)$. 
Table ( 3 ). The rate of eyes infection according to months in Baghdad.

\begin{tabular}{|l|l|l|}
\hline Months & Number of cases infected & Infection rate from 30 samples \\
\hline Jan. & 2 & $6.66 \%$ \\
\hline Mar. & $6^{*}$ & $20 \%$ \\
\hline Apr. & $11^{*}$ & $36.66 \%$ \\
\hline May. & 3 & $10 \%$ \\
\hline Jun. & 3 & $10 \%$ \\
\hline Jul. & 2 & $6.66 \%$ \\
\hline Des. & 3 & $10 \%$ \\
\hline
\end{tabular}

$*$ Refer to presence of significant value vertically at $(\mathrm{P} \leq 0.05)$.

Table ( 4 ). The rate of eyes infection according to dogs breeds in Baghdad.

\begin{tabular}{|l|l|l|}
\hline Breed & Number of cases infected & Infection rate from 30 samples \\
\hline Husky & 3 & $10 \%$ \\
\hline Labrador & 1 & $3.34 \%$ \\
\hline Terrier & $6^{*}$ & $20 \%$ \\
\hline Rottweiler & 3 & $10 \%$ \\
\hline $\begin{array}{l}\text { German } \\
\text { shepherd }\end{array}$ & $8^{*}$ & $26.66 \%$ \\
\hline Lolo fox & 2 & $6.66 \%$ \\
\hline Pit bull & 1 & $3.34 \%$ \\
\hline Black jack & 1 & $3.34 \%$ \\
\hline fox terrier & 2 & $6.66 \%$ \\
\hline local breed & 3 & $10 \%$ \\
\hline
\end{tabular}

*Refer to presence of significant value vertically at $(\mathrm{P} \leq 0.05)$. 
Table ( 5). The rate of eyes infection according to dogs sex in Baghdad.

\begin{tabular}{|l|l|l|}
\hline Sex & Number of cases infected & Infection rate from 30 samples \\
\hline Male & $24 *$ & $80 \%$ \\
\hline Female & 6 & $20 \%$ \\
\hline
\end{tabular}

$*$ Refer to presence of significant value vertically at $(\mathrm{P} \leq 0.05)$.

Table (6). The rate of eyes infection according to dogs breeds in Baghdad.

\begin{tabular}{|l|l|l|}
\hline Ages & Number of cases infected & Infection rate from 30 samples \\
\hline$>$ 1year & 6 & $20 \%$ \\
\hline$<$ year-4years & 11 & $36.6 \%$ \\
\hline$\leq 5$ years & 13 & $43.4 \%$ \\
\hline
\end{tabular}

*Refer to presence of significant value vertically at $(\mathrm{P} \leq 0.05)$.

\section{DISCUSSION}

Many studies reported conjunctiva micro-flora, ten eyes swab were cultured in this study from healthy dogs without clinical signs and these cultures were negative. That is main may no normal flora in the eye conjunctiva, this resultwas different with many studies most general bacteria were diagnosed gram-positive and gram negative as normal eye flora includeStaphylococcus spp., Corynebacteriumspp., Streptococcus spp.,Bacillus spp., Pseudomonas aeruginosa and Corynebacteriumspp. and others(Kudirkienè et al. 2006; and Prado, 2005;Grahn, 2004). The our study revealed no growth in culture of healthy eyes dogs that is main there is no normal flora in the conjunctiva and disagree with all previousremembered studies, the interpretation of this result the conjunctiva is sterile sac and the number non pathogens organisms arecultivated from normal conjunctiva very small (Malathi et. al., 2003) because mechanically washing of the conjunctiva from foreign bodies as bacteria fungal by the tearsevery few seconds and locally presence lysozyme, $\operatorname{IgG}$, and IgA as bacteriostatic substancesand low blood supply inhibits the microorganisms growth(Singer et. al., 1988).

Staphylococcus spp. was the most frequently isolated genus, followed by Escherichia col , which represented $22.5 \%$ of the isolates, this results agree with (Prado et al 2006)wasdetected Staphylococcus spp. more frequently genus $(45.2 \%)$, but followed by Corynebacterium spp.

Junior et al (2012) reported Gram-positive bacteria (76\%) more than Gram-negative in (20\%) and fungal in (4\%) in dogs with eyes diseases, while we reported Gram-positive bacteria (39.28\%), Gram-negative in (28.51\%) and fungal in $(21.42 \%)$, these results of conducted study revealed statistically the eye infection in dogs bacterial in origin (67.79\%) but no 
significant differences $(\mathrm{P} \leq 0.05)$ between gram positive and gram negative bacteria.whereas the fungal was uncommon infection and significantly decrease $(\mathrm{P} \leq 0.05)$ in dogs, fungal infection, particularly occurred when the presence of predisposing factors moisture humidity, seasonal variation, immunosuppressive drugs and as secondary infection (Zenad et al., 2015).

The infection rate in the our study of signs of eyes diseases, specially conjunctivitis and lacrimation associated with canine distemper is $(10.71 \%)$, CDV had many clinical signs and the suppurative conjunctivitis one of typical signs of this diseases but uncommon in occurrence (Qiu et al., 2011). The Aspergillus is the pathogens considered secondary to the eyes infection by Escherichia coli and CDV, the Aspergillus considered common fungal for oculardiseases in dogs(Day, 2006 and Schultz et al., 2008). The chance of eye infection by Salmonella spp. and diagnosis CDV occurred in one case in our study, the Salmonella spp. is important pathogen as secondary infection with CDV and shedding the Salmonella spp. in surrounded dogs environment sometimes lead to death (Shabbir et. al., 2010), Conjunctivitis has been reported incatswith predisposing factors, such as immunosuppressive or surgery, can be outbreak occurs as secondary disease in a carrier animal(Carter and Quinn, 2000). Whereas in dogs no found any reference reported conjunctivitiswithSalmonella spp. in dogs, and our study first report conjunctivitisby Salmonella spp. with CDV in dogs.

Prado et al (2006) estimated twelve dogs breeds and found there was no significant difference $(\mathrm{P} \leq 0.05)$ between the breeds in the incidence of eyes diseases, despite of our study recorded significantly higher $(\mathrm{P} \leq 0.05)$ was in Terrier and German shepherd, may be the cause of this results because increase the chance of organism isolate from long haired breeds compare to the other breeds(Kudirkienè et al. 2006) and we noticed the population of Terrier and German shepherd dogs high in baghdad that increase the clinical cases which reached to Baghdad veterinary hospital.

Prado et. al. (2006) and Gelatt (2000) were signed increase incidence of eyes diseases in males dogs compared to females, these results compatible with present our study, the risk factor of male eyes diseases was increased because more aggressive than females, and this reason increase healthy problem in males (Matos et. al., 2015).

\section{CONCLUSION}

The normal flora in the eye conjunctiva of dogs is very small or none, Staphylococcus spp. and Escherichia coli were major pathogen of eyes infection in dogs. The fungaleyes infection is secondary infection and sources of infection to eyes from hair or skin, the seasonal variation through months is considered an essential factor in eyes infection, the CDV has important role in conjunctivitis.

\section{REFERENCES}

Asghari A. and Gharachorlou, A. (2011) Assessingthe role of proper administration of antibioticsin the treatment of corneal ulcers in dog.Adv. Environ. Biol. 5: 2084-2086.

Gemensky-MetzlerA.J., WilkieD.A., KowalskiJ.J., Schmall L.M., Willis A.M. and YamagataM. (2005). Changes in bacterial and fungal ocularflora of clinically normal horses followingexperimental application of topical antimicrobialor antimicrobial-corticosteroid ophthalmicpreparations. Am J Vet Res. 66: 800-811. 
Grahn B. H., Peiffer R. L., Cullen C. L. and Haines D. M. (2003). Histochemical and imunohistochemical evaluation of 75 felineintraocular neoplasms. Proceedings of Annual Meeting of theAmerican College of Veterinary Ophthalmologists, 20-23.

Prado M. R., Rocha M. F, Brito E. H., Girão M.D., Monteiro A.J., Teixeira M. F. andSidrim J. J. (2005). Survey of bacterialmicroorganisms in the conjunctival sac of clinically normaldogs and dogs with ulcerative keratitis in Fortaleza, Ceará,Brazil. Vet. Ophtalmol.Vol. 1. P. 33-37.

Miller P. and Murphy C. J.(1995) Vision in dogs. J. Am. Vet. Assoc. Vol. 207. P.1623.

Salisbury M.A., Kaswan R. L. and Brown J.(1995) Microorganisms isolated from the corneal surface before and during topical cyclosporine treatment in dogs with KCS, Am. J. Vet. Res. Vol. 56. P. 880-884.

Massa K. L., Murphy C. J., Hartmann F. A., Miller P. E., Korsower C. S. and Young K.M. (1999) Usefulness of aerobic microbial culture and cytological evaluation of corneal specimens in the diagnosis of infectious ulcerative keratitis in animals. J. Am. Vet. Med. Assoc. Vol. 215. 1671-1674.

Haghkhah M., Sarchahi A. A. andMolazem M. (2005).Conjunctival flora in normal dogs. Journal of Veterinary Research. Vol. 9. P. 79-83.

Gerding PA and KakomaI (1990). Microbiology of the canine and feline eye. Vet. Clin. North Am.: Small Anim. Pract. 20: 615-625.

WangL., PanQ., ZhaNGL.,XueQ., Cui J., QiC. (2008). Investigation of bacterial microorganisms in the conjunctival sac of clinically normal dogs and dogs with ulcerative keratitis in Beijing, China. Veterinary Ophthalmology, v. 11, n. 3, p. 145-149.

Akpek, E.K. and Gottsch, J.D. (2003). Immune defense at the ocular surface. Eye (Lond). 17, 949-956.

Leigue L., Montiani-Ferreira F. and Moore B.A. (2016). Antimicrobial susceptibility and minimal inhibitory concentration of Pseudomonas aeruginosa isolated from septic ocular surface disease in different animal species. Open Veterinary Journal, Vol. 6(3): 215-222.

Ibrahim S and Rahma MA (2009). Isolation and identification of fungi associated with date fruits (Phoenixdactylifera, Linn), sold at Bayero university, Kano, Nigeria, Bayero. Journal of Pure and Applied Sciences, 2(2): 127-130.

Cheesbrough M (2000). District Laboratory Practice in Tropical Countries Part 2. Cambridge University Press, Cambridge, PP: 47-54.

Greene CE and Apple MJ (2006). Canine Distemper In: Infectious Diseases of the dog and cat. Greene CE, Saunders, $3^{\text {rd }} E d .: 25-41$.

Soma T,Ishii H, Hara M, Ohe K, Hagimori I, Ishikawa Y and Taneno A. (2003) Detection of canine distemper virus antigen in canine serum and its application to diagnosis. Vet Records 18:499-501. 
Kudirkienè E., Žilinskas H. andŠiugždaitèJ.(2006). Microbial flora of dogs eyes.Veterinarijair Zootechnika. T. 34 (56). 2006.

Prado M.R.,Brito E.H.S.,Girão M.D.,Sidrim J.J.C. and RochaM.F.G. (2006). Identification and antimicrobial susceptibility of bacteria isolated from corneal ulcers of dogs. Arq. Bras. Med. Vet. Zootec. vol.58 no.6.

Junior A. Z., Freitas J. C., Zacarias F. G. S., Salvador R., Garcia J. L.(2012). Investigation of bacterial microbiota and risk factors in dogs with external ocular diseases from Bandeirantes, Paraná State, Brazil. Semina: CiênciasAgrárias, Londrina, v. 33, suplemento 2, p. 3243-3250.

Zenad M. M., Badawi N. M. and Abdul-Raheem Abdul-JalilWali AR. AJ.(2015).Cross Sectional Study on Cutaneous Mycotic Infections of Dogs and Cats in Baghdad.World Vet J, 5(4): 66-73.

Qiu W., Zheng Y., Zhang S., Fan Q., Liu H., Zhang F., Wang W., Liao G., and Hu R. (2011). Canine Distemper Outbreak in Rhesus Monkeys, China. Emerging Infectious Diseases Vol. 17, No. 8:1541-1543.

Schultz R. M., Johnson E. G., Wisner E. R., Brown N. A., Byrne B. A., and Sykes J. E.(2008). Clinicopathologic and diagnostic imaging characteristics of systemic aspergillosis in 30 dogs. J Vet Intern Med 22:851-859.

Day M. J. (2006). Aspergillosis and Penicilliosis, p. 613-626. In: C. E. Greene (ed.), 3rd ed. Elsevier, St Louis, Missouri.

Malathi J, Madhavan HN, Therese KL and Joseph PR.(2003). A hospital based study on the prevalence of conjunctivitis due to Chlamydia trachomatis. Indian J Med Res.; 117: 71-75.

Singer TR, Isenberg SJ and Apt L.(1988). Conjunctival anaerobic and aerobic bacterial flora in paediatric versus adult subjects. Br J Ophthalmol. 72: 448-451.

Gelatt K. N. (2000). Canine Anterior Uvea: Diseases and Surgery: Essentials of Veterinary Ophthalmology, philadel phialippincott Williams \& wilkins, P:197-225.

R.E. Matos, T. Jakuba, I. Mino, M. Fejsakova, A. Demeova, J. Kottferova (2015). Characteristics and risk factors of dog aggression in the Slovak Republic.VeterinarniMedicina, 60, (8): 432-445

Shabbir MZ, Rabbani M, Ahmad a, Ahmed a, Muhammad K, Anwar I (2010).Comparative evaluation of clinical samples from naturally infected dogs for early detection of canine distemper virus. Turkish Journal of Veterinary and Animal Sciences 34 (6), 547-552.

Carter M. E. and Quinn J.(2000). Salmonella Infections in Dogs and Cats, Chapter 14 Faculty of Veterinary Medicine, University College Dublin,Ballsbridge, Dublin 4, Ireland P: 231-244.

Quinn, P.J.; Carter, M.E.; Markey, B. and Carter, J.R. (2004). Clinical Veterinary Microbiology. $6^{\text {th }}$ Ed. Mosby Wolf, London. 